\title{
ФИНЛЯНДИЯ: ЭЛЕКТОРАЛЬНЫЕ ИТОГИ 2019
}

Аннотация. На парламентских выборах в апреле 2019 г. наибольшее число голосов набрала Социал-демократическая партия Финляндии (СДПФ), которая получила право формировать правительство. Начионалистическая партия «Истинные финньл» незначительно уступила СДПФ, но сотрудничество между ними оказалось невозможным, особенно после смень руководства у «Истинных финнов», перешедших на ещё более радикальные позиции. Переговоры сочиал-демократов с другими партиями увенчались формированием левочентри-стского правительства большинства, в которое кроме СДПФ вошли Финляндский центр, Шведская народная партия, Левый союз и Зелёные. Эта комбинация не гарантирует устойчивость правительства в условиях усиливщейся поляризачии политического пространства.

Ключевые слова: Финляндия, парламент Финляндии, «Истинные финньл», Ю. Халла-ахо, партия Финляндский Центр, Ю. Сипиля, Социал-демократическая партия Финляндии, А. Ринне.

16 апреля 2019 г. состоялись очередные выборы в финский парламент. Предсказать победителей было сложно, поскольку две сильные партии - Финляндский Центр (ФЦ) и «Истинные финны» (ИФ) оказались в нелёгком положении. Первая из них возглавляла коалиционное правительство, которое было вынуждено ещё в марте уйти в отставку после неудач с реформами социального обеспечения и регионального управления. А «Истинные финны» претерпели раскол. После того, как на съезде этой партии был избран новый председатель - Юсси Халла-ахо, который зарекомендовал себя ярым националистом, выступавшим против мусульман и некоторых этнических групп и ратующим за ужесточение финской иммиграционной политики, часть членов партии вышла из неё и образовала фракцию «Новая альтернатива» (в дальнейшем она конституировалась в партию «Синее будущее»). Тот факт, что члены этой фракции были против нового руководства партии, избавило страну от правительст-венного кризиса: четыре министра кабинета Ю. Сипиля, вышедшие из партии «Истинные финны», остались на своих постах.

У «Истинных финнов» существовали опасения, что раскол ослабит партию, и она потеряет голоса избирателей. Однако результаты выборов были восприняты как несомненная победа нового лидера: 17,5\% голосов, как и на предыдущих выборах, в то время как на «Синее будущее» пришёлся лишь $1 \%{ }^{1}$. В итоге «Истинные финны» вновь оказались второй партией, а Финляндский Центр с 13,8\% голосов лишь четвёртой - худший результат за 100 лет.

Наибольшее число голосов получила Социал-демократическая партия Финляндии -

\footnotetext{
(C) Плевако Наталия Сергеевна - кандидат исторических наук, ведущий научный сотрудник, руководитель Центра Северной Европы Отдела страновых исследований Института Европы РАН. Адрес: 125009, Россия, Москва, Моховая ул., д. 11, стр. 3. E-mail: natalia_plevako@mail.ru.
}

DOI: http://dx.doi.org/10.15211/vestnikieran420192731

${ }^{1}$ Mandatfördelningen enligt parti. URL: https://vaalit.yle.fi/ev2019/sv/parties (дата обращения: 23.07.2019). 
17,7\%, которая уже 20 лет находилась в оппозиции, на третьем месте - Коалиционная партия - 17\%. Таким образом, ни одна партия не только не набрала большинства голосов избирателей, но и не доказала обоснованность претензий на национальное лидерство ${ }^{1}$.

Политические обозреватели указывают на прогрессирующую фрагментацию политических сил, что характерно ныне и для других стран Европы. В отличие от Швеции в Финляндии сильна традиция формирования правительства, опирающегося на твердое парламентское большинство. Председатель СДПФ А. Ринне, которому было поручено формирование правительства, стал активно искать возможных партнёров по коалиции. ${ }^{2}$ У традиционных финских партий (так же как и у датских) нет идиосинкразии в отношении националистов, с которыми у них деловые отношения в парламенте и даже в правительстве. И несмотря на неодобрение смены руководства в партии «Истинные финны», ни одна партия после выборов категорично не высказалась о невозможности сотрудничать с ней. А. Ринне отметил, что «по его мнению, все крупные партии Финляндии готовы нести ответственность за страну, что должно способствовать быстрому решению проблемы власти» ${ }^{3}$, добавив, что все находятся в равных стартовых условиях. И это отражает традиционную прагматичность финской политики. Приступая к переговорам с партиями, которые прошли в парламент, А. Ринне не заострял внимания на критике «Истинных финнов» и не исключал участия в коалиции откровенно провалившегося Финляндского Центра. Вместе с тем очевидно, что усилившийся критический настрой по отношению к «Истинным финнам» после смены у них руководства не помешал ужесточению позиций относительно иммиграционной политики у некоторых партий. Существовали также опасения, что если социал-демократы не смогут сформировать правительственную коалицию, то эту задачу придётся решать второй по результатам голосования партии - «Истинным финнам», а этого не хотел никто. Такая ситуация оказалась на руку СДПФ.

Сам лидер «Истинных финнов» Ю. Халла-ахо достаточно реалистично оценивал ситуацию, понимая, что преимущественное право выбора союзника находится у других партий. Вместе с тем, он подчёркивал, что ИФ готовы сотрудничать со всеми партиями, но не любой ценой, особенно учитывая опыт вхождения в правительство в предыдущей легислатуре, когда его партии пришлось идти на уступки в иммиграционной политике. Именно испытание правительственной властью окончилось расколом партии, поэтому пребывание в оппозиции в данный момент, видимо, представляется более выгодным вариантом для ИФ, успешно выступивших на выборах и понимающих, что, находясь в активной оппозиции, они привлекут новые голоса избирателей на следующих выборах. Но есть и определённые риски. Как отмечает политолог Й. Юпсунд, роль и возможности влияния оппозиционных партий изменились с принятием новой Конституции. Если раньше для принятия решений было необходимо согласие $2 / 3$ или $5 / 7$ состава парламента, то теперь достаточно простого большинства. Из этого Й. Юпсунд делает вывод, что большинство партий стремится войти в правительство и готово ради этого поступиться некоторыми своими принципами ${ }^{4}$.

\footnotetext{
${ }^{1}$ Увеличили своё представительство в парламенте партия Зелёных (11,5\%), а также Левый союз (8,2\%). Неудачно выступила Шведская народная партия $(4,5 \%)$, оставшись с тем же, что и ранее числом мандатов. Христианские демократы прибавили $0,4 \%$, что не повлияло на число её представителей в парламенте.

${ }^{2}$ Иначе обстояло дело в Дании, где в июне также прошли парламентские выборы и больше всего голосов набрала социал-демократическая партия, руководство которой, однако, сразу заявило, что намерено сформировать правительство меньшинства с поддержкой его со стороны партий «красного» блока.

3 Antti Rinne utlovar en jämställd regering före slutet av maj. URL: https://svenska.yle.fi/artikel/2019/04/18/antti-rinneutlovar-en-jamstalld-regering-fore-slutet-av-maj (дата обращения: 18.04.2019).

${ }^{4}$ Experterna: Så kan den nya regeringen se t.15.04.2019. URL: https://svenska.yle.fi/artikel/2019/04/15/experterna-saНаучно-аналитический вестник ИЕ РАН, 2019, №4
} 
В свою очередь Коалиционная партия расширила перечень проблем, по которым она выразила готовность сотрудничать с социал-демократами. Основные споры между социал-демократами и коалиционерами всегда касались проблем экономической политики, в частности, налогов. Именно в этой области, как полагал председатель партии П. Орпо, возможен и необходим компромисс с СДПФ. Он выдвинул предложение о снижении налогов на трудовую и предпринимательскую деятельность и повышении налогов на промышленные отходы и использование природных ресурсов. Подобные предложения вписывались П. Орпо в понятие «ответственной экономической политики», необходимой для устойчивого развития. Однако переговоры пошли трудно, и СДПФ отказалась от привлечения этой правой партии в правительство.

В переговорах по формированию правительства А. Ринне решил опираться на ключевого игрока предыдущего правительства - Финляндский центр, ещё совсем недавно самую крупную и популярную в стране партию. Но шок и растерянность от сокрушительного поражения на последних парламентских выборах были настолько велики, что вопрос об участии в правительстве вначале даже не обсуждался. Надо было думать о смене председателя партии и мерах по восстановлению доверия избирателя. Однако постепенно стали проявляться признаки оживления дискуссии об участии в правительстве ценой отказа от «правого политического курса», проводившегося партией в предыдущие годы. Вновь избранный руководитель парламентской фракции А. Кайкконен заявил, что «дверь в правительство пока приоткрыта, и мы как ответственная партия не собираемся её запирать» ${ }^{1} .80 \%$ членов совета, правления и парламентской группы партии поддерживают переговоры о формировании правительства при условии, что будут выполнены все требования ФЦ². Они касались сбалансирования госу-дарственных финансов к 2023 г. без увеличения корпоративных налогов и финансового бремени фермеров, реформы региональной администрации, увеличения небольших пенсий и уве-личения лесозаготовок, что может привести к уменьшению поглотителей выбросов от сжигания углеводородов. А это уже противоречит амбициозным требованиям партии Зелёных.

Однако заручившись поддержкой Финляндского Центра и имея таким образом 71 мандат из 200, социал-демократам необходимо было идти дальше, чтобы получить превалирующее число мандатов по сравнению с оппозицией. Переговоры о будущем правительстве шли и с малыми партиями, такими как, центристская Шведская народная партия (ШНП), выступающая от лица шведского меньшинства. Начиная с 1972 по 2015 гг., ШНП непрерывно уча-ствовала в коалиционных правительствах, добавляя свои голоса формирующим правительства партиям. В партии полагают, что при нынешнем раскладе ШНП была бы мостом, соединяющим разнородные политические силы.

Удачно в 2019 г. выступили две партии левого толка - Зелёные (20 мандатов) и Левый союз (16 мандатов), на поддержку которых надеялись социал-демократы. В некоторых районах страны они намного улучшили результаты предыдущих выборов. Особенно популярной стала руководитель Левого союза, активная, харизматичная Ли Андерссон, которая вышла на второе место по полученным персональным голосам. Красно-зеленые стали активными уча-стниками переговорного процесса, тем более что темы экологии,

kan-den-nya-regeringen-se-ut (дата обращения: 18.04.2019).

${ }^{1}$ Juha Sipilä blir en riksdagsman i mängden och spår opposition för Centern. 23.04.2019. URL: https://svenska.yle.fi/ artikel/2019/04/23/juha-sipila-blir-en-riksdagsman-i-mangden-och-spar-opposition-for-centern (дата обращения: 23.04.2019).

${ }^{2}$ Centre Party to Join SDP, 3 others in Government Talks. 08.05.2019. URL: https://yle.fi/uutiset/osasto/news/centre_ party_to_join_sdp_3_others_in_government_talks/10772412 (дата обращения: 20.07.2019). 
изменения климата стали едва ли не центральными в предвыборной гонке. Успех левых партий наряду с победой «Истинных финнов» свидетельствует о поляризации политических сил в стране, в то время как доверие к партиям мейнстрима падает.

О создании правительства было объявлено 6 июня, в него вошли пять партий: СДРФ, Финляндский центр, Шведская Народная партия, Левый союз и Зелёные. Ключевые посты помимо социал-демократов (министры внешней торговли и развития кооперации, занятости, министр по европейским делам, социальных служб и семьи) заняли представители Финляндского центра (министры финансов, обороны, науки и культуры, сельского и лесного хозяйства, экономического развития), «Зелёных» (министры иностранных дел, окружающей среды и климата), Левого союза (министры образования, социального развития и здравоохранения), Шведской народной партии (министры юстиции, кооперации северных стран и равенства). Таким образом, было сформировано левоцентристское правительство, состоящее из конгломерата разнородных партий. В ближайшее время значительное внимание будет уделено проблемам изменения климата и устойчивого развития. Это зафиксировано не только в програм-ме, обнародованной финским правительством после выборов, но и в документе, который был представлен в связи с председательством Финляндии в Европейском союзе. Что касается им-миграционной политики, то новое правительство будет проводить более щедрую политику в этой области, чем предыдущее. А это в свою очередь усилит критику со стороны «Истинных финнов» и вполне вероятно прибавит им популярности.

Конечно, парламентские выборы 2019 г в Финляндии не относятся к категории судьбоносных. После них мало что поменяется в жизни финского народа. Но можно обратить внимание на некоторые тенденции, проявившиеся на выборах. В дальнейшем они могут привести к серьёзным политическим сдвигам в этой стране. Во-первых, налицо поляризация электоральных пристрастий, свидетельствующая об ослаблении центристских политических течений и укреплении позиций фланговых партий. При возможном обострении экономической или политической ситуации в стране, вызванном не только внутренними процессами, но, возможно, даже внешним воздействием, общественнополитические конфликты могут принять острые формы. Во-вторых, заметны последствия фрагментации политического прост-ранства: ни одна из партий не способна взять на себя роль ведущей силы, что особенно замет-но в деле формирования правительства. Нагромождение согласований, уступок и компромис-сов создаёт ситуацию, при которой правительство приобретает черты технического кабинета, стремящегося не столько находить новые пути развития, сколько удержать ситуацию под контролем. А это чревато распадом коалиций и правительственными кризисами.

\section{Список литературы}

Юссила О., Хентиля С., Невакиви Ю. Политическая история Финляндии 1809-2009 М., Издательство «Весь Мир», 2010.

Могунова М.А. Государственное право Финляндии. Городец. 2005.

\section{References}

Yussila O., Hentilya S., Nevakivi YU. Politicheskaya istoriya Finlyandii 1809-2009 M., Izdatel'stvo «Ves' Mir», 2010.

Mogunova M.A. Gosudarstvennoe pravo Finlyandii. Gorodec. 2005. 
Kovalenko N.E. Mestnoe samoupravlenije kak forma demokratii. Spb., 2008.

Timonen V. Restructuring the Welfare State. Globalisation and Social PolicyReform in Finland and Sweden. Cheltenham, 2003.

Antti Rinne utlovar en jämställd regering före slutet av maj. URL: https://svenska. yle.fi/artikel/2019/04/18/antti-rinne-utlovar-en-jamstalld-regering-fore-slutet-av-maj.

Experterna: Så kan den nya regeringen set. 15.04.2019. URL: https://svenska.yle.fi/artikel/ 2019/04/15/experterna-sa-kan-den-nya-regeringen-se-ut.

Juha Sipilä blir en riksdagsman i mängden och spår opposition för Centern. 23.04.2019. URL: https://svenska.yle.fi/artikel/2019/04/23/juha-sipila-blir-en-riksdagsman-i-mangden-och-sparopposition-for-centern/

Centre Party to Join SDP, 3 others in Government Talks. 8.5.2019 URL: https://yle.fi/uutiset/ osasto/news/centre_party_to_join_sdp_3_others_in_government_talks/10772412.

\section{Finland: Electoral Results 2019}

Author. Natalya Plevako, Candidate of Sciences (History), Head of the Centre for Northern Europe Studies, Department of Countries Studies, Institute of Europe, Russian Academy of Sciences. Address: 11-3, Mokhovaja str., Moscow, Russia, 125009. E-mail: natalia_plevako@mail.ru.

Abstract. In the parliamentary elections in April 2019 the Social Democratic Party of Finland won the largest number of votes receiving the right to form a government. The number of votes of the nationalist party «True Finns» slightly conceded to the SPD, but cooperation between them was impossible, especially after the change of leadership of the «True Finns», who moved to even more radical positions. Negotiations of the Social Democrats with other parties culminated in the formation of a center-left majority government, which in addition to the SPD included the Finland's Center, the Swedish People's party, the Left Union and the Greens. This combination does not guarantee the stability of the government in the conditions of increased polarization of the political space.

Keywords: Finland, Parliament of Finland «True Finns», J. Halla-Aho, the Finnish Centre party, J. Sipilä, the Social democratic party of Finland, A. Rinne.

DOI: http://dx.doi.org/10.15211/vestnikieran420192731 